\title{
RELATIONSHIP BETWEEN PRE- AND POST-THROMBOSIS FACTORS IN PATIENTS WITH STAGE VD CKD TREATED BY LONG-TERM HEMODIALYSIS
}

DOI: $10.36740 /$ WLek202103116

\author{
Oleksiy B. Storozhuk', Sergiy V. Shevchuk', Larysa O. Storozhuk², Tetyana V. Dovgalyuk², Borys G. Storozhuk ${ }^{1}$ \\ 'NATIONAL PIROGOV MEMORIAL MEDICAL UNIVERSITY, VINNYTSIA, UKRAINE \\ 2RESEARCH INSTITUTE OF REHABILITATION OF NATIONAL PIROGOV MEMORIAL MEDICAL UNIVERSITY, VINNYTSIA, UKRAINE
}

\begin{abstract}
The aim: To determine informative value of pre-thrombosis, post-thrombosis and anticoagulation factors as well as their correlations for assessment of hemostasis status in patients with stage VD CKD.

Materials and methods: Potential predictors of thrombophilia development as well as their relationships depending on the level of molecular markers of hemostasis were studied in 88 patients with stage VD CKD undergoing long-term hemodialysis with the view to determine their informative value.

Results: Accumulation of soluble fibrin (SF) was demonstrated to cause moderate reaction of D-dimer (D-d) being insufficient in the absence of reaction of anticoagulant component of hemostasis. Soluble fibrin levels were found to be associated with D- $d$ concentration $(r=0.39)$ and functionally inactive prothrombin forms (FIPF) to some extent $(r=-0.24)$. Accumulation of FIPF in individuals with high level of $s F$ implies significant activation of blood coagulation system at the stage prior to thrombin formation. Absence of close relationship between pre- and post-thrombosis indices may be indicative of still preserved potential of anticoagulant component of hemostasis.

Conclusions: Accumulation of FIPF is an early marker of activation of blood coagulation and possible thrombosis. Levels of $s F$ correlate with pre-thrombosis (fibrinogen, FIPF) and post-thrombosis (D-d) factors being associated with inhibition of anticoagulation processes. Comprehensive study of basic components of hemostasis in patients with VD stage of chronic kidney disease offer broader opportunities in arranging prophylactic measures to prevent thrombophilia.
\end{abstract}

KEY WORDS: VD CKD (VD stage of chronic kidney disease), hemodialysis, hemostasis, soluble fibrin, D-dimer, ( protein, fibrinogen, functionally inactive prothrombin forms

$\overline{\text { Wiad Lek. 2021;74(3 p.l):471-474 }}$

\section{INTRODUCTION}

Disturbance of homeostasis leading to thrombosis development is known to be one of the commonest complications in patients with stage $\mathrm{V}$ chronic kidney disease (CKD) treated by long-term hemodialysis [1]. Thrombophilia syndrome, as the process of intravascular thrombogenesis, is defined by systemic activation of blood coagulation in the absence of anticoagulant and fibrinolytic compensation $[2,3,4]$. Therefore, study of hemostasis is of great significance and should be based on comprehensive analysis of hemostatic parameters and their relationships for unbiased evaluation of blood coagulation processes. Soluble fibrin $(\mathrm{sF})$, D-dimer $(\mathrm{D}-\mathrm{d})$, fibrinogen $(\mathrm{Fg})$, protein $\mathrm{C}(\mathrm{pC})$, functionally inactive prothrombin forms (FIPF) as well as D-d/ $\mathrm{sF}$ and $\mathrm{pC} / \mathrm{Fg}$ ratios in patients with stage $\mathrm{V}$ CKD, treated by long-term hemodialysis, were studied to estimate informative value and associative relationships between thrombogenesis activators and its inhibitors as thrombophilia markers.

\section{THE AIM}

To determine informative value of pre-thrombosis, post-thrombosis and anticoagulation factors as well as their relationships for assessment of hemostasis status in patients with stage VD CKD.

\section{MATERIALS AND METHODS}

Blood sampling was taken in study patients and healthy volunteer donors (after receiving their informed consent) on empty stomach into vacutainer containing sodium citrate solution. Plasma was obtained after 20 minute centrifugation with relative centrifugal force $1200-1400 \mathrm{~g}$.

Soluble fibrin was determined by two-site enzyme-linked immunosorbent assay [5]. D-dimer was estimated by enzyme immunoassay using monoclonal antibodies to D-dimer epitopes [5]. Protein C activity in blood plasma was estimated by its activation with copperhead snake venom, by spectrophotometry with wavelength of 405 and $492 \mathrm{~nm}$ [6]. Blood plasma fibrinogen content was determined by spectrophotometry using Antsistron-H (thrombin-like enzyme) [7]. Functionally inactive prothrombin forms (FIPF) were calculated by the ratio of ecamulin and prothrombin indices [8].

\section{RESULTS}

According to soluble fibrin level, study patients were divided into three groups: group $1-\mathrm{sF}$ less than or equal to 3.0 $\mu \mathrm{g} / \mathrm{ml}(\mathrm{n}=28)$; group $2-\mathrm{sF} 3.1-3.9 \mu \mathrm{g} / \mathrm{ml}(\mathrm{n}=37)$; group $3-\mathrm{sF} 4.0 \mu \mathrm{g} / \mathrm{ml}$ and over $(\mathrm{n}=23)$. 
Table I. Relationship between pre- and post-thrombosis factors in patients with stage VD CKD.

\begin{tabular}{|c|c|c|c|c|c|c|c|}
\hline \multirow[b]{2}{*}{ No } & \multirow{2}{*}{$\begin{array}{c}\text { Groups of patients with } \\
\text { stage VD CKD } \\
n=88\end{array}$} & \multirow[b]{2}{*}{$\mathbf{n}$} & \multicolumn{5}{|c|}{ Hemostasis parameters } \\
\hline & & & $\begin{array}{c}s F, \\
\mu g / m l\end{array}$ & $\begin{array}{c}\text { D-dimer, } \\
\mathrm{pg} / \mathrm{ml}\end{array}$ & $\begin{array}{c}\text { Fg, } \\
\mathrm{mg} / \mathrm{ml}\end{array}$ & pC, \% & FIPF, \% \\
\hline \multirow{3}{*}{1} & $\mathrm{sF}<3.0 \mu \mathrm{g} / \mathrm{ml}$ & 28 & - & $45.3 \pm 5.85$ & $3.88 \pm 0.20$ & $83.0 \pm 2.88$ & $103.4 \pm 3.6$ \\
\hline & $\mathrm{sF} 3.1-3.9 \mu \mathrm{g} / \mathrm{ml}$ & 37 & - & $66.1 \pm 5.22 *$ & $4.44 \pm 0.19^{*}$ & $82.7 \pm 2.57$ & $111.0 \pm 3.82$ \\
\hline & $\mathrm{sF}>4.0 \mu \mathrm{g} / \mathrm{ml}$ & 23 & - & $126.7 \pm 22.6^{*}$ & $4.03 \pm 0.25$ & $78.9 \pm 3.41$ & $113.8 \pm 3.87^{*}$ \\
\hline \multirow{3}{*}{2} & $\mathrm{Fg}<3.3 \mathrm{mg} / \mathrm{ml}$ & 17 & - & $68.5 \pm 7.52$ & - & $83.1 \pm 3.64$ & $106.9 \pm 4.75$ \\
\hline & $\mathrm{Fg} 3.3-4.7 \mathrm{mg} / \mathrm{ml}$ & 47 & - & $79.0 \pm 12.6$ & - & $84.1 \pm 2.12$ & $108.4 \pm 2.67$ \\
\hline & $\mathrm{Fg}>4.7 \mathrm{mg} / \mathrm{ml}$ & 24 & - & $73.1 \pm 9.36$ & - & $76.5 \pm 3.54$ & $113.2 \pm 5.33$ \\
\hline \multirow{2}{*}{3} & $\mathrm{pC}>85 \%$ & 38 & - & $60.6 \pm 5.75$ & $3.95 \pm 0.16$ & - & $105.2 \pm 3.30$ \\
\hline & $\mathrm{pC}<85 \%$ & 50 & - & $86.8 \pm 11.9^{*}$ & $4.31 \pm 0.17$ & - & $112.3 \pm 2.91$ \\
\hline \multirow{2}{*}{4} & FIPF $<110 \%$ & 48 & - & $69.8 \pm 8.94$ & - & $84.5 \pm 2.20$ & - \\
\hline & FIPF $>110 \%$ & 40 & - & $82.0 \pm 12.03$ & - & $78.6 \pm 2.48$ & - \\
\hline
\end{tabular}

Note: * - significant difference as compared to patients with low levels of D-d, Fg, pC and FIPF.

Table II. Correlation coefficients between indices of blood coagulation system in patients with stage VD CKD ( $n=88)$.

\begin{tabular}{ccccccc}
\hline \multirow{2}{*}{ No } & $\begin{array}{c}\text { Hemostasis } \\
\text { indices }\end{array}$ & SF & D-d & PC & Fg & FIPF \\
\cline { 3 - 6 } & sF & - & - & - & - \\
\hline 1 & $\mathrm{D}-\mathrm{d}$ & $0.39^{*}$ & - & - & - \\
\hline 3 & $\mathrm{pC}$ & -0.10 & $-0.21 \#$ & - & - \\
\hline 4 & $\mathrm{Fg}$ & -0.12 & -0.01 & -0.19 & - \\
\hline 5 & $\mathrm{FIPF}$ & $-0.24 \#$ & -0.15 & $-0.21 \#$ & 0.02 & - \\
\hline 6 & $\mathrm{D}-\mathrm{d} / \mathrm{sF}$ & 0.05 & $0.87^{*}$ & -0.06 & 0.01 & - \\
\hline 7 & $\mathrm{pC} / \mathrm{Fg}$ & 0.06 & -0.05 & $0.65^{*}$ & $-0.81^{*}$ \\
\hline
\end{tabular}

Notes: ${ }^{*}$ - significant correlation coefficient; \# - moderate correlation relationship

Given that increased soluble fibrin concentration can serve as pre-thrombosis indicator, the decision was made to study all other indices of hemostasis and to grade the levels of other parameters (Fg, pC, FIPFs) as well as their correlations (Table I).

Analysis of sF concentrations in study groups, as well as their comparison with general group has shown normal fibrin values only in 28 patients $(31.8 \%)$. The changes in other components of hemostasis were studied in the groups of patients with various $\mathrm{sF}$ levels as well. Sequential significant increase in $\mathrm{D}$-dimer value reflecting post thrombosis process was detected in groups $1-3(\mathrm{p}=0.05 \div 0.01)$. Such increase in $\mathrm{D}$-dimer level along with considerable increase in soluble fibrin concentration should be regarded as the process of fibrinolysis, suggesting an increased risk of thrombosis in those patients. However, a tendency to $\mathrm{pC}$ decrease was found in group $3(\mathrm{pC}>4.0 \mu \mathrm{g} / \mathrm{ml})$. It should be noted that patients of group 3 proved to have significant accumulation of early markers of pre-thrombosis - FIPF. Fibrinogen, being known as the source of fibrin, characterizes general potential of coagulation system, and its concentration is directly influenced by concentration of soluble fibrin and should be comparable with it. This statement was evidenced by generally high fibrinogen concentration in all three groups: blood plasma fibrinogen level was increased in $93.2 \%$ of patients. At the same time, high fibrinogen concentration along with normal $\mathrm{sF}$ values was observed in group $1(\mathrm{sF}<3.0 \mu \mathrm{g} / \mathrm{ml})$. Increased $\mathrm{Fg}$ concentration had no significant influence on post-thrombosis $\mathrm{D}$-d values followed by the tendency of decrease in $\mathrm{pC}$ level.

It should be emphasized that values of natural anticoagulant - protein $\mathrm{C}$ - do not correspond to high potential risk of thrombosis. Table 1 shows low level of protein $\mathrm{C}$ in all the groups, and in $56.8 \%$ of patients it was lower the borderline values, being indicative of inadequate proportional anticoagulant reaction to procoagulant status in hemodialysis patients. It is well known that index of accumulation of functionally inactive prothrombin forms can serve as an additional marker in detection of thrombophilia [9], since the amount of FIPF increases in thrombosis development, as thrombin breaks down prothrombin to build up inactive form of pre-thrombin I [9]. FIPF is thought to be the first early marker of activation of blood coagulation system, since it is produced in all pathological conditions associated with thrombogenesis [9]. High soluble fibrin level is known to be associated with increased FIPF accumulation in $70 \%$ of cases, while the presence of FIPF was detected in $44 \%$ of individuals with decreased level of physiological blood clotting inhibitor $\mathrm{pC}$ [10], which was demonstrated in our study. Comparison of patients with the ratio of ecamulin 
index to prothrombin index $>110 \%$, corresponding to FIPF level of $1.2 \mu \mathrm{g} / \mathrm{ml}$ and above [8], and those with FIPF level $<110 \%$ showed no significant differences in those groups, except for the tendency to decreasing D-d level in the latter group. Those data demonstrate again the absence of clotting and fibrinolysis processes at the stage of FIPF accumulation.

Correlation relationships between soluble fibrin and D-dimer, fibrinogen, $C$ protein and FIPF were assessed in general group, and the following data were obtained: medium direct relationship between soluble fibrin and $\mathrm{D}$-dimer $(\mathrm{r}=0,39 ; \mathrm{p}=0,02)$, absence of correlation with fibrinogen $(r=-0.12)$, protein $C(r=-0.10)$ as well as with $\mathrm{D}-\mathrm{d} / \mathrm{sF}$ and $\mathrm{pC} / \mathrm{Fg}$ ratios (Table II). On the other hand, moderate negative relationship was observed between $\mathrm{sF}$ and FIPF $(r=-0,24 ; p=0,05)$. $D-d$ showed high positive correlation relationship with $\mathrm{D}-\mathrm{d} / \mathrm{sF}$ ratio $(\mathrm{r}=0,87 ; \mathrm{p}=$ $0,001)$ and moderate negative - with $\mathrm{pC}(\mathrm{r}=-0,21 ; \mathrm{p}=$ $0,05)$. Moderate direct relationship between $\mathrm{pC}$ and $\mathrm{pC} /$ Fg ratio $(r=0,65 ; p=0,01)$ as well as moderate negative relationship between $\mathrm{pC}$ and $\mathrm{FIPF}(\mathrm{r}=-0,21 ; \mathrm{p}=0,05)$ were revealed. Besides, strong negative relationship between $\mathrm{Fg}$ and $\mathrm{pC} / \mathrm{Fg}$ ratio $(\mathrm{r}=-0,81 ; \mathrm{p}=0,001)$ was observed.

\section{DISCUSSION}

According to the results of studies, two thirds of patients treated by program hemodialysis have high concentrations of soluble fibrin in blood plasma. This implies activation of blood coagulation system and the risk of thrombotic complications [4]. Since hemodialysis sessions are associated with constant damage to the formed elements of blood and entry of platelet coagulation factors into the bloodstream, plasma precursor of platelet state is activated triggering the activation of blood clotting processes through intrinsic pathway in hemostasis system with accumulation of soluble fibrin [5].

Thus, in response to accumulation of soluble fibrin, moderate reaction of $\mathrm{D}$-dimer develops, though inadequate to our opinion, but the reaction of anticoagulant component of hemostasis is absent. However, strong correlation relationship was found between soluble fibrin level and D-d concentration $(r=0,39 ; p=0,02)$ and FIPF to some extent $(\mathrm{r}=-0,24 ; \mathrm{p}=0,05)$. Accumulation of FIPF in individuals with high $\mathrm{sF}$ level by contrast to those with its low level suggests significant activation of blood coagulation system at the stage prior to thrombin formation [11]. The absence of close relationships between pre- and post-thrombosis indices may be indicative of preserved potential function of anticoagulant system in patients with VD CKD. Thus, those data confirm FIPF accumulation to be rather early marker of activation of coagulation system and possible thrombosis [8]. Stable moderate negative correlation between FIPF and $\mathrm{C}$ protein, which is known to be not only a physiological inhibitor of activation of blood coagulation system but also a regulator of fibrinolysis system, was observed as well $[8,12]$. Such depressive state of anticoagulant component along with activation of coagulation factors may be one of conditions leading to thrombophilia.

\section{CONCLUSIONS}

1. There is close relationship between $s F$ level and pre-thrombosis factors - Fg and FIPF, as well as between $\mathrm{sF}$ and post-thrombosis factor - D-d.

2. Increased $\mathrm{sF}$ concentration is associated with depressive state of anticoagulant component of hemostasis presented by $\mathrm{pC}$.

3. Accumulation of FIPF along with decreased activity of natural anticoagulant $-\mathrm{pC}$, may be one of predictors of thrombotic complications development in patients with VD CKD.

Directions for future research: Comprehensive study of major components of hemostasis in patients with VD stage of CKD provides opportunity of extending prophylactic measures to prevent thrombophilia.

\section{REFERENCES}

1. Melnik A. Sistema gemostaza i yeye regulyatsiya pri narushenii funktsional'noy sposobnosti pochek. [System of hemostasis and its regulation in renal dysfunction]. News of Medicine and Pharmacy in Ukraine. 2016;9(583):24-31. (in Russian).

2. Heit J. Thrombophilia: common questions on laboratory assessment and management. Hematology Am Soc Hematol Educ Program. 2007;1:127-135.

3. Bernakevich A., Vasiliev C., Eskin N. Sostoyaniye sistemy gemostaza u patsiyentov, podvergayushchikhsya endoprotezirovaniyu tazobedrennogo sustava [Status of hemostasis system in patients undergoing hip replacement]. Journal of Traumatology and Orthopedics. 2009;1:37-41. (in Russian).

4. Shevchuk S., Gornytska 0., Chernyshenko T. et al. Kompleksna diahnostyka trombofiliyi za systemnoho chervonoho vovchaka [Comprehensive diagnostics of thrombophilia in systemic lupus erythematosus]. Laboratory Diagnostics. 2010;1:3-8. (in Ukrainian).

5. Lugovskoi E., Kolesnikova M., Lugovskaya N. et al. Kolichestvennoye opredeleniye D-dimera i rastvorimogo fibrina v plazme krovi cheloveka pri ishemicheskoy bolezni serdtsa i gipertonicheskoy bolezni [Quantitative determination of D-dimer and soluble fibrin in blood plasma of patients with ischemic heart disease and hypertension]. Ukrainian Biochemistry Journal. 2006;78(4):120-129. (in Russian).

6. Platonova T., Gornytska 0., Moroz E. Zastosuvannya aktyvatoru proteyinu S z otruty shchytomordnyka zvychaynoho (Agkistrodon halys halys) dlya vyznachennya aktyvnosti proteyinu $S$ u plazmi krovi za riznykh patolohiy [Use of protein C activator from copperhead snake venom (Agkistrodon halys halys) to determine the activity of protein Cin blood plasma in various pathologies]. Laboratory Diagnostics. 2004;3:28-31. (in Ukrainian).

7. Sokolovska A., Platonova T., Grynenko T. et al. Porivnyal'na kharakterystyka metodiv vyznachennya vmistu fibrynohenu v plazmi krovi [Comparative characteristics of methods to determine blood plasma fibrinogen content]. Experimental and Clinical Physiology and Biochemistry. 2002;3:82-86. (in Ukrainian).

8. Storozhuk L., Shevchuk S., Storozhuk B. et al. Kliniko-laboratorna diahnostyka trombofiliy u khvorykh XXHVD stadiyi, shcho perebuvayut' na prohramnomu hemodializi [Clinical and laboratory diagnosis of thrombophilia in patients with stage VD CKD undergoing long-term hemodialysis]: Methodical recommendations. Vinnytsia: FOP Rogalska I.0. 2017. (in Ukrainian). 
9. Storozhuk 0., Selezneva I., Storozhuk L. et al. Funktsional'no neaktyvni formy protrombinu ta riven' fibrynohenu, yak markery hiperkoahulyatsiyi u khvorykh na khronichnu khvorobu nyrok VD stadiyi, yaki perebuvayut' na prohramnomu hemodializi [Functionally inactive forms of prothrombin and fibrinogen level as markers of hypercoagulation in patients with chronic kidney disease VD stage undergoing long-term hemodialysis]. Bulletin of Vinnytsia National Medical University. 2017;21(2):450-453. (in Ukrainian).

10. Mosnier L., Mejers J., Bouma B. The role of protein C in activation of thrombin activatable fibrinolysis inhibitor (TAFI) and regulation of fibrinolysis. Thrombosis and Haemostasis. 2001;86(4):1040-1046.

11. Dohlback B., Villoutreix B. Regulation of blood coagulation by the protein C anticoagulant pathway. Arteriosclerosis, Thrombosis and Vascular Biology. 2005;15:1311-1320.

12. Volkov G., Platonova T., Savchuk A. et al. Sovremennyye predstavleniya 0 sisteme gemostaza. [Modern ideas on hemostasis system]. Kyiv: Naukova dumka; 2005. (in Russian).

The article is a part of systematic research work "To determine the role of pro- and anticoagulant factors of hemostasis and parameters of clotting potential in development of comorbid conditions in patients with chronic kidney disease VD stage and to develop criteria for thrombophilia prevention", state registration number $0119 U 101156$.

\section{ORCID and contributionship:}

Tetyana V. Dovgalyuk: 0000-0003-1614-9021 B,D

Oleksiy B. Storozhuk: 0000-0003-4400-4719 A,B,D

Sergiy V. Shevchuk: 0000-0002-5649-2775 ${ }^{E, F}$

Larysa O. Storozhuk: 0000-0002-4591-9534 ${ }^{A, B, D}$

Boris G. Storozhuk: 0000-0002-9590-2159 A,C,D

\section{Conflict of interest:}

The Authors declare no conflict of interest.

\section{CORRESPONDING AUTHOR \\ Boris G. Storozhuk \\ National Pirogov Memorial Medical University \\ 56 Pirogova st., 21018 Vinnytsia, Ukraine \\ tel: $+38050-313-3302$ \\ e-mail: storozhuk0323@gmail.com}

Received: 14.04 .2020

Accepted: 12.11 .2020

A - Work concept and design, B - Data collection and analysis, C - Responsibility for statistical analysis,

D-Writing the article, $\mathbf{E}$-Critical review, $\mathbf{F}$ - Final approval of the article 